\title{
Evaluation of cottonseed oil-cake meal as a protein source in calf starter meals
}

\author{
N.M. Bangani, C.J.C. Muller ${ }^{\#}$ and J.A. Botha \\ Department of Economic Affairs, Agriculture \& Tourism: Western Cape, Private Bag X1, Elsenburg 7607, \\ Republic of South Africa
}

\begin{abstract}
The growth performance of 18 Holstein and 20 Jersey heifer calves fed calf starter meals containing either cottonseed oil-cake meal (CSOCM) or soybean oil-cake meal (SBOCM) was compared. The diets were isonutritious in terms of crude protein and energy, and were fed from two weeks of age until two or three months of age to Holstein or Jersey calves respectively. Jersey and Holstein calves weighed $21.4 \pm 0.5$ and $35.9 \pm 1.4 \mathrm{~kg}$ respectively at the start of the experiment. There were no differences between calf starter meals containing CSOCM or SBOCM $(p>0.05)$ in respect of feed intake, growth rate or efficiency of feed conversion. Average daily gain of Jersey and Holstein heifer calves was $0.435 \pm 0.02$ and $0.635 \pm 0.03 \mathrm{~kg} /$ day respectively. No calves died during the experiment. It was concluded that the most important criterion for inclusion of CSOCM in calf starter meals is the cost of CSOCM relative to that of SBOCM, provided that the CSOCM used has a gossypol content of less than $200 \mathrm{ppm}$.
\end{abstract}

Key words: heifer calves, cottonseed oil-cake meal, soybean oil-cake meal, growth rate, gossypol, mortality.

\#Author to whom correspondence should be addressed. E-mail: carelm@wcape.agric.za

\section{Introduction}

Although cottonseed oil-cake meal (CSOCM) has long been recognized as an economical protein source for dairy cow diets, it is potentially toxic when fed to calves (Risco et al., 1992). Cottonseed products contain gossypol, a yellow, polyphenolic binapthylaldehyde that is toxic for monogastric animals (Gray et al., 1993). In ruminants, gossypol is detoxified in the rumen either by bonds formed with soluble proteins or by a dilution effect, which results in slower absorption of gossypol. Young calves, however, function as monogastric animals until the rumen is fully developed and are therefore more susceptible to gossypol poisoning. Nonetheless, CSOCM is sometimes included in dairy calf diets under practical farming conditions, apparently without ill effects. The objective of this study was to compare CSOCM with soybean oil-cake meal (SBOCM) to determine the suitability of locally-produced CSOCM for inclusion as a protein sources in calf starter meals.

\section{Materials and methods}

Eighteen Holstein and 20 Jersey calves were randomly allocated to calf starter meals containing either $8 \%$ CSOCM or $8 \%$ SBOCM (Table 1). The diets contained similar levels of crude protein, total digestible nutrients and crude fibre. The ratio of calcium to phosphorus was 1:1 as recommended by NRC (1989). The experiment began when calves were 14 days old and was terminated when Jersey calves were three months of age and Holstein calves were two months of age. Calves were fed whole milk (3-4 1/day) twice daily prior to the start of the experiment and were encouraged to eat the calf starter meal by placing meal into the buckets after they had finished drinking milk. Calves were weaned at 35 days of age and thereafter they received only calf starter meal ad libitum. Fresh water was freely available from day 10. The quantity of meal offered was increased on an individual basis whenever there were no residues left over from the previous day. Feed intake of calves was monitored twice weekly. Calves were kept in individual stalls and were weighed once weekly. Feed samples were collected once weekly, dried at $55^{\circ} \mathrm{C}$ for three days to determine dry matter content and analyzed for contents of crude protein, crude fibre (AOAC, 1990) and total digestible nutrients (Engels \& Van der Merwe, 1967). Data were analyzed by analysis of variance (Statgraphics, 1993).

\section{Results and discussion}

There were no differences between diets in respect of dry matter intake, feed conversion efficiency or average daily gain $(p>0.05)$ between diets for calves of either breed (Table 2$)$. These results are in agreement with those of El-Din et al. (1992) and Biondi et al. (1993) who also reported no differences between diets containing 
CSOCM and SBOCM. The free gossypol content of the experimental calf starter meal used in the current trial was $162 \pm 43 \mathrm{ppm}$. No calves died and neither were symptoms of gossypol toxicity observed. Similar findings were reported by Biondi et al. (1993). Risco et al. (1992) found that a diet containing $200 \mathrm{ppm}$ free gossypol was safe for Holstein bull calves from 1 to 120 days of age, but that $400 \mathrm{ppm}$ was toxic, and that $800 \mathrm{ppm}$ resulted in deaths.

Table 1 Physical and chemical composition of calf starter meals containing cottonseed oil-cake meal (CSOCM) or soybean oil-cake meal (SBOCM)

\begin{tabular}{lll}
\hline \multirow{2}{*}{ Parameters } & \multicolumn{2}{c}{ Calf starter meal } \\
\cline { 2 - 3 } Ingredients (kg) & CSOCM & SBOCM \\
Lucerne hay & & \\
Wheat & 86 & 82 \\
Maize & 610 & 565 \\
CSOCM & 150 & 200 \\
SBOCM & 80 & - \\
Fishmeal & - & 80 \\
Limestone & 63 & 63 \\
Salt & 6 & 5 \\
& 5 & 5 \\
Chemical composition (\% of DM) & & \\
& & \\
Crude protein & & \\
Crude fibre & 18.9 & 19.0 \\
TDN ${ }^{1}$ & 7.6 & 7.0 \\
Calcium & 80.5 & 81.4 \\
Phosphorus & 0.56 & 0.57 \\
\hline Total digestible nutrients & 0.58 & 0.57 \\
\hline
\end{tabular}

Table 2 Body mass, average daily gain (ADG), dry matter intake (DMI) and efficiency of feed conversion (EFC) of Jersey and Holstein calves receiving calf starter meals containing cottonseed oil-cake meal (CSOCM) or soybean oil-cake meal (SBOCM) as protein sources

\begin{tabular}{|c|c|c|c|c|}
\hline & \multicolumn{2}{|c|}{ Calf starter meal } & \multirow[b]{2}{*}{$P^{*}$} & \multirow[b]{2}{*}{$\mathrm{SEM}^{+}$} \\
\hline & CSOCM & SBOCM & & \\
\hline \multicolumn{5}{|l|}{ Jersey calves } \\
\hline Initial mass (kg) & 21.8 & 21.1 & 0.48 & 0.47 \\
\hline Final mass (kg) & 54.6 & 55.2 & 0.88 & 2.00 \\
\hline $\mathrm{ADG}$ & 0.43 & 0.44 & 0.74 & 0.22 \\
\hline DMI/day & 0.93 & 1.00 & 0.42 & 0.04 \\
\hline Total DMI & 72.7 & 76.8 & 0.51 & 3.0 \\
\hline EFC (kg/kg DMI) & 0.469 & 0.464 & 0.91 & 0.02 \\
\hline \multicolumn{5}{|l|}{ Holstein calves } \\
\hline$\overline{\text { Initial mass }(\mathrm{kg})}$ & 32.8 & 30.5 & 0.43 & 1.42 \\
\hline Final mass (kg) & 67.6 & 64.0 & 0.44 & 2.2 \\
\hline $\mathrm{ADG}$ & 0.66 & 0.65 & 0.66 & 0.03 \\
\hline DMI/day & 1.18 & 1.20 & 0.86 & 0.06 \\
\hline Total DMI & 55.4 & 56.3 & 0.87 & 2.9 \\
\hline $\mathrm{EFC}(\mathrm{kg} / \mathrm{kg}$ DMI $)$ & 0.58 & 0.54 & 0.57 & 0.35 \\
\hline
\end{tabular}

"significance level; ${ }^{+}$standard error of mean 


\section{Conclusions}

It was concluded that this particular source of CSOCM could be used as a protein source for calves, and that the most important criterion for inclusion of CSOCM in calf starter meals is the cost of CSOCM relative to that of SBOCM, provided that the gossypol content is less than $200 \mathrm{ppm}$.

\section{Acknowledgements}

The authors thank A. Shipman and his staff for the care and management of the experimental animals. The help of the Elsenburg Bio- and Datametrical Section for datametrical services is gratefully acknowledged.

\section{References}

AOAC, 1990. Association of official analytical chemists. Official methods of analysis. Vol. 1. $15^{\text {th }}$ edition. AOAC, Arlington, Virginia, USA.

Biondi, P., Delistoianov, J. \& Ribeiro, W.R., 1993. The effect of soybean meal, cottonseed meal and fish meal in dairy calf feeding. Boletim-De Industria Animal. 50, 87.

El-Din, A.E.T., Nour, A.M., Shazly, K. \& Hassan, E., 1992. Evaluation of soybean and glandless cottonseed meal. Indian J. Anim. Sci. 62, 677.

Engels, E.A.N. \& Van Der Merwe, F.J., 1967. Application of an in vitro technique to South African forages with special reference to the effect of certain factors on the results. S. Afr. J. Agric. Sci. 10, 983.

Gray, M.L., Randel, R.D., Green, E.W.L. \& Williams, G.L., 1993. Metabolic homeostasis and reproductive endocrine function in post-pubertal beef heifers fed varying levels of free gossypol. J. Anim. Sci. 68, 1.

NRC, (1989).National Research Council. Nutrient Requirements of Domestic Animals. 6th Edition, National Academy Press, Washington, DC, USA.

Risco, C.A., Holmberg, C.A. \& Kutches, A., 1992. Effect of graded concentrations of gossypol on calf performance: Toxicological and pathological consideration. J. Dairy Sci. 75, 2787.

Statgraphics, 1993. Statistical graphics system by Statistical graphics corporation. Bitstream Inc. Cambridge, MA. USA. 